\title{
SINDROM DELIRIUM AKUT
}

\author{
Nidya Angryni1 ${ }^{1)}$, Roza Mulyana ${ }^{2)}$ \\ ${ }^{1}$ Fakultas Kedokteran, Universitas Andalas, Bagian Penyakit Dalam RSUP Dr.M.Djamil Padang \\ email: dr.nidya@gmail.com
}

Submitted : 30-04-2020, Reviewer: 05-05-2020, Accepted: 05-05-2020

\begin{abstract}
Abstrak
Sindrom delirium akut merupakan sebuah sindrom neuropskiatrik yang kompleks dengan onset akut dan besifat fluktuatif. Sindrom ini melibatkan suatu hendaya fungsi kognitif yang akut dan menyeluruh yang mempengaruhi kesadaran, perhatian, memori, kemampuan perencanaan, dan organisasi. Telah dilaporkan kasus sindrom delirium akut pada pasien laki-laki usia 75 tahun. Pasien datang dengan perubahan kesadaran yang terjadi 2 hari terakhir. Sindrom delirium akut yang terjadi pada pasien didasari atas infeksi paru. Pada pemeriksaan fisik paru didapatkan ronkhi basah halus nyaring di kedua lapangan paru. Pada pasien juga ditemukan adanya sindrom geriatri yang meliputi imobilisasi dengan ketergantungan total, instabilitas dengan risiko jatuh, malnutrisi, frailty, dan gangguan penglihatan. Pada pasien dilakukan penanganan secara komprehensif dalam tim medis interdisipliner dengan partisipasi keluarga yang merupakan salah satu pendekatan pelayanan geriatri paripurna.
\end{abstract}

Kata kunci: Sindrom Delirium Akut, Geriatri.

\begin{abstract}
Acute confusional state is a complex neuropsychiatric syndrome with acute onset and fluctuating. This syndrome involves an acute and comprehensive cognitive function that influences awareness, attention, memory, planning and organizational abilities. There has been reported case of acute confusional state in 75-year-old male patient. Patient present with changes in consciousness that occurred last 2 days. Acute confusional state that occur in patients based on lung infection. On physical examination of the lungs, a soft, wet crackling crack was found in both lung fields. In patients also found geriatric syndrome which includes immobilization with total dependence, instability with a risk of falling, malnutrition, frailty, and impaired vision problems. Patients are treated comprehensively in an interdisciplinary medical team with family participation, which is one of the most complete geriatric service approaches.
\end{abstract}

Keywords: Acute Delirium Syndrome, Geriatrics.

\section{PENDAHULUAN}

Sindrom delirium akut merupakan sebuah gangguan yang umum, serius, tetapi secara potensial dapat dicegah. Delirium merupakan sumber morbiditas dan mortalitas di antara pasien-pasien geriatri yang dirawat. Hal ini penting karena pada pasien geriatri, kejadian delirium menghabiskan $48 \%$ dari seluruh hari perawatan di rumah sakit. Insiden delirium juga meningkat sejalan dengan pertambahan usia populasi. ${ }^{1}$
Delirium adalah sebuah sindrom neuropsikiatrik yang kompleks dengan onset yang akut dan berfluktuasi. Sindrom ini melibatkan suatu hendaya fungsi kognitif yang akut dan menyeluruh yang mempengaruhi kesadaran, perhatian, memori, dan kemampuan perencanaan dan organisasi. Gangguan lain, misalnya pola tidur yang berubah, gangguan proses pikir, afek, persepsi, dan tingkat keaktifan, walaupun dipandang tidak bermakna namun mempunyai kontribusi yang besar dalam mengidentifikasi dan menatalaksana delirium. ${ }^{1,2}$ 
Walaupun terdapat banyak sekali faktor risiko yang mencerminkan karakteristik perjalanan dari pasien, beberapa faktor risiko dapat dimodifikasi untuk mencegah kejadian delirium. Delirium juga sering dialami oleh pasien sesudah operasi. Kondisi khusus, misalnya luka bakar, HIV/AIDS, fraktur, hipoksemia, insufisiensi organ, infeksi, serta gangguan metabolik juga dapat merupakan faktor risiko terjadinya delirium. ${ }^{1,3}$

Penyebab delirium menurut salah satu teori adalah terdapatnya defisiensi neurotansmiter asetilkolin serta dopaminergik. Pada geriatri terdapat defisiensi relatif asetilkolin hasil metabolisme oksidatif otak sehingga terjadi disfungsi mental. Neurotransmiter asetilkolin berperanan sangat penting dalam awareness. Dopamin adalah neurotransmiter yang sangat penting bagi fungsi motorik, perhatian, serta kognisi. ${ }^{4}$

Penatalaksanaan delirium tentunya tidak terpisah dari penyebabnya. Identifikasi penyakit yang mendasari serta pengobatan secara tepat perlu dilakukan. Penatalaksanaan pasien geriatri perlu dilakukan secara paripurna yang dikenal sebagai comprehensive geriatric assessment secara bersama dalam tim medis interdisipliner dengan partisipasi keluarga sehingga pasien berusia lanjut memiliki derajat kesehatan optimal dan kemampuan fungsional tertinggi. ${ }^{1,5,6}$

\section{LAPORAN KASUS}

Seorang pasien laki-laki 75 tahun datang dengan keluhan perubahan kesadaran yang disadari keluarga sejak 2 hari sebelum masuk rumah sakit. Pasien terkadang dapat kontak dengan keluarga, namun pasien lebih banyak tampak mengantuk.

Pasien memiliki riwayat DM tipe 2, hipertensi dan strok yang diketahui sejak tahun 2015. Pasien telah mengalami 3 kali stroke berulang. Kelopak mata kanan pasien melemah dan tidak bisa menutup sejak 5 tahun terakhir sehingga mata kanan menjadi kering dan kemerahan. Pasien lebih banyak terbaring di tempat tidur sejak 2 tahun terakhir, lemah anggota gerak sebelah kanan sehingga tangan kanan dan kaki kanan pasien tampak semakin mengecil dan kaku. Penurunan nafsu makan sejak 1 tahun ini. Pasien makan 1-2 kali sehari dan hanya bisa menghabiskan setengah porsi dari biasanya.

Pasien mengalami demam sejak 1 minggu sebelum masuk rumah sakit (SMRS). Batuk sejak 5 SMRS dan sesak nafas sejak 3 hari SMRS. Pada riwayat pengobatan sebelumnya diketahui pasien pasca rawat di RS swasta dengan diagnosis recurrent stroke. Pasien diizinkan pulang namun pasca rawat pasien mengalami perburukan dan kemudian dirawat di RSUP Dr.M.Djamil Padang.

Pada pemeriksaan fisik ditemukan kesadaran somnolen, tampak sakit berat, tekanan darah 160/90 $\mathrm{mmHg}$, nadi 80 kali.menit, frekuensi nafas $23 \mathrm{kali} / \mathrm{menit}$, dan suhu $37,8^{\circ} \mathrm{C}$. Pada pasien ditemukan injeksi konjungtiva (OD), injeksi siliar (OD), lagoftalmus (D), dan moderate NPDR (OS).

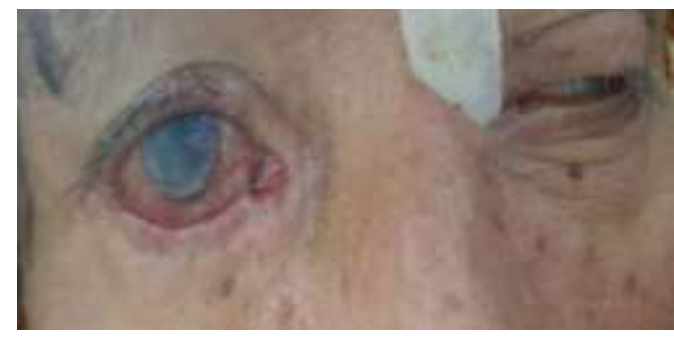

Gambar 1. Injeksi konjungtiva (OD), injeksi siliar (OD), lagoftalmus (D), dan moderate NPDR (OS).

Pada pemeriksaan paru didapatkan ronkhi basah halus nyaring di kedua lapangan paru. Pemeriksaan ekstremitas 
menunjukkan hemiparese dekstra. Activity Daily Living (ADL) Barthel pasien tergolong pada ketergantungan total. Skor Geriatric Depression Scale (GDS) dan Abbreviated Mental Test (AMT) pasien sukar dinilai. Hasil pemeriksaan Mini Nutritional Assesment (MNA) pasien termasuk kategori malnutrisi. Pengkajian risiko ulkus dekubitus/skala Norton pada pasien yaitu dengan peningkatan risiko ulkus dekubitus sebesar 50 kali. Status frailty pasien yaitu dengan akumulasi defisit (FI 40) sebesar 0,65 dengan interpretasi nilai frail. Skor CURB-65 dengan risiko mortalitas dalam 30 hari sebesar $6,8 \%$.

Pemeriksaan penunjang menunjukkan

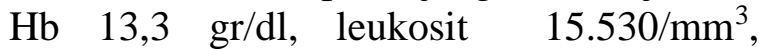
trombosit $477.000 / \mathrm{mm}^{3}$, hitung jenis leukosit 0/2/0/77/17/4. Kadar gula darah sewaktu $152 \mathrm{mg} / \mathrm{dl}$, natrium $119 \mathrm{mmol} / \mathrm{L}$, kalium $3,8 \mathrm{mmol} / \mathrm{L}$, albumin serum $3,0 \mathrm{~g} / \mathrm{dl}$ , ureum $19 \mathrm{mg} / \mathrm{dl}$, dan kreatinin $0,8 \mathrm{mg} / \mathrm{dl}$. Pemeriksaan rontgen toraks memberikan kesan bronkopneumonia. Pemeriksaan kultur sputum menunjukkan hasil klebsiella pneumonia.

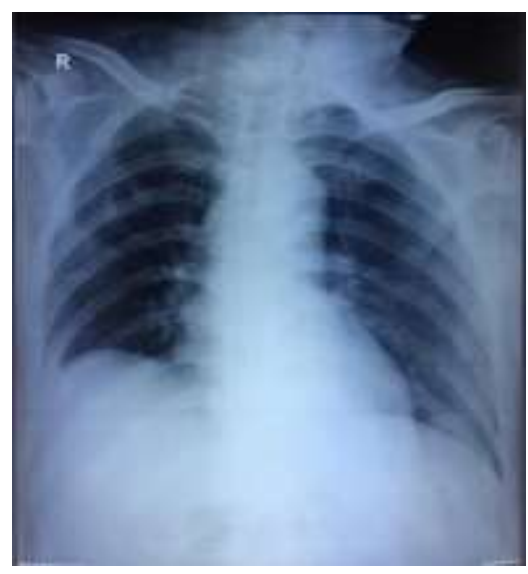

Gambar 2. Rontgen toraks.

Pasien diberikan terapi IVFD $\mathrm{NaCl} 3 \%$ $12 \mathrm{jam} / \mathrm{kolf}$, injeksi cefepim $3 \times 1 \mathrm{gr}$, infus levofloxacin 1x500 mg, nebu $\mathrm{N}$-asetil sistein $18 \mathrm{jam}$, paracetamol $3 \times 500 \mathrm{mg}$ (po), amlodipine 1 x $10 \mathrm{mg}$ (po), metformin $3 \mathrm{x}$ $500 \mathrm{mg}$, clopidogrel $1 \times 75 \mathrm{mg}$ (po), cendo lyters ed 6x1 (OD), salep kloramfenikol 1\% 3x1 (OD), levofloxacin ed 6x1 (OD), EDTA 6x1 (OD), Tetrasiklin 3x1 (OD), dan sulfas atropin $3 \times 1$ (OD). Nutrisi enteral diberikan berupa makanan cair sebanyak $700 \mathrm{kkal}$ dan dinaikkan secara bertahap sampai $1400 \mathrm{kkal}$ yang diberikan via NGT. Nutrisi parenteral yang diberikan yaitu Aminofluid $500 \mathrm{ml}(20$ jam) dan clinoleic $20 \% 100 \mathrm{ml}$ (4 jam). Mikronutrien yang diberikan yaitu vitamin B complex 3 x 2 tablet (po).

Pada pasien dilakukan passive ROM exercise, weight shifting yaitu miring kanan dan kiri tiap 2 jam, edukasi oral hygiene tiap hari, menjaga kelembaban dan kebersihan kulit, serta pemasangan kasur dekubitus untuk mencegah terjadinya ulkus dekubitus pada pasien dengan imobilisasi lama.

\section{DISKUSI}

Telah dirawat pasien laki-laki usia 75 tahun dengan sindrom delirium akut, hospital acquired pneumonia, sindrom geriatri (imobilisasi dengan ketergantungan total, instabilitas dengan risiko jatuh, malnutrisi, dan frailty), DM tipe 2, hipertensi stage II, hiponatremia, hipoalbuminemia, sequele stroke infark, keratitis eksposur OD, ulkus kornea OD, lagoftalmus OD, dan moderate NPDR OS.

Masalah utama pada pasien ini adalah sindrom delirium akut. Pada pasien geriatri, delirium berhubungan dengan perpanjangan waktu tinggal di rumah sakit, peningkatan mortalitas, dan peningkatan beban biaya pengobatan. Delirium biasanya bersifat reversible jika penyebab yang mendasarinya teridentifikasi. Gejala delirium sangat beragam dan walaupun tidak spesifik, sifatnya yang fluktuatif sangat nyata dan merupakan indikator diagnostik yang sangat penting. Terdapat tiga bentuk delirium yang telah diketahui yaitu tipe hiperaktif, 
hipoaktif, dan campuran. Tipe hipoaktif seringkali tidak dikenali dan dihubungkan dengan prognosis yang buruk secara keseluruhan. $^{2}$

Pada pasien ini faktor risiko terjadinya delirium adalah infeksi paru yaitu hospital acquired pneumonia (HAP). Infeksi sangat erat kaitannya dengan penurunan fungsi sistem imun pada usia lanjut. Kondisi lain seperti kurang gizi, multipatologi, dan faktor lingkungan dapat memudahkan usia lanjut terkena infeksi. Pada kondisi infeksi terdapat peningkatan sitokin proinflamasi, ditambah dengan adanya defisiensi neurotransmiter akibat hipoksemia, akan menyebabkan terjadinya gangguan transduksi sinyal dan menimbulkan manifestasi klinis sindrom delirium akut. Data pada divisi Geriatri Departemen Ilmu Penyakit Dalam FKUI/RSCM Jakarta tahun 2003 menunjukkan pneumonia sebagai diagnosis terbanyak di ruang rawat akut geriatri dengan insiden sebesar 52,2 \% dengan mortalitas sebesar 30,3 \%. Tatalaksana HAP pada geriatri adalah dengan pemberian antibiotik adekuat. Antibiotik pilihan adalah cefepime ditambah makrolide atau fluoroquinolon generasi ke 2 dan 3. Pada pasien ini diberikan cefepime dan levofloxacin dengan respon pengobatan baik. Pasien memperlihatkan respon yang baik setelah 3 hari pemberian antibiotik. Antibiotik pada pasien diberikan selama 7 hari, sesuai dengan American Thoracic Society dengan lama pemberian antibiotik selama 5-10 hari. $^{7}$

Selain itu, pasien ini juga mengalami sindrom geriari berupa gangguan penglihatan, imobilisasi, instabilitas, malnutrisi, dan frailty. Sindrom geriatri adalah kondisi klinis pada lanjut usia dimana terdapat gangguan multiple, berbeda dengan penyakit kronis lainnya, kumpulan gejala dari sindrom ini tidak memenuhi kriteria penyakit lain. Masalah yang sering di jumpai pada sindrom geriatri adalah imobilisasi, instabilitas, inkontinensia, insomnia, depresi, infeksi, defisiensi imun, gangguan pendengaran, gangguan penglihatan, gangguan intelektual, kolon irritable, impecunity, malnutrisi, impotensi, dan frailty. ${ }^{8,9}$

Pasien ini mengalami gangguan penglihatan. Saat awal terkena stroke, pasien kesulitan dalam menutup kelopak mata kanannya sehingga mata menjadi kering. Pasien tidak dapat memejamkan mata bahkan pada saat tidur. Awalnya pasien merasakan mata yang nyeri dan gatal. Kemudian bola mata menjadi keruh dan terjadi tukak pada lapisan luar mata. Perubahan penglihatan sudah mulai dirasakan dan sangat mengganggu. Proses penuaan dan adanya infeksi juga berperan besar dalam perubahan tersebut. Gangguan penglihatan merupakan salah satu masalah kesehatan yang terkait dengan proses penuaan. Gangguan penglihatan berhubungan dengan kualitas hidup, dapat meningkatkan disabilitas fisik, ketidakseimbangan, berisiko mengalami cedera karena terjatuh, bahkan mengalami depresi akibat gangguan tersebut. ${ }^{10,11}$

Lagoftamus pada pasien ini merupakan kelainan pada mata yang disebabkan karena kelopak mata tidak dapat menutup bola mata. Hal tersebut dapat disebabkan oleh karena bola mata yang menonjol keluar, kelumpuhan kelopak mata, dan kelopak mata tertarik akibat jaringan parut. Kelainan tersebut mengakibatkan mata tidak dilindunngi oleh kelopak mata sehingga mudah terjadi radang pada mata. Selain itu, lagoftalmus juga dapat terjadi akibat kelumpuhan saraf facialis (N VII) yang mengontrol fungsi kelopak mata. Kelumpuhan ini bisa bersifat sementara atau permanen dan dapat disebabkan oleh stroke, tumor otak, atau trauma. Keadaan tersebut dapat menjadi serius seperti yang dialami pasien yaitu mekanisme berkedip tidak 
dapat berfungsi lagi sehingga mata pasien menjadi kering, nyeri, dan iritasi. Kekeringan pada mata yang berkepanjangan dapat menyebabkan kehilangan penglihan dan hal ini sangat berpengaruh terhadap kualitas hidup pasien. Pada pasien ini diberikan pengobatan berupa salep mata dan obat tetes mata yang bertujuan untuk mengatasi keluhan mata yang dialami pasien. $^{12}$

Sindrom geriatri yang lain dialami pasien ini yaitu imobilisasi. Imobilisasi adalah keadaan tidak bergerak / tirah baring selama 3 hari atau lebih, diiringi gerak anatomis tubuh yang menghliang akibat perubahan fungsi fisiologis. Imobilisasi menyebabkan komplikasi lain yang lebih besar pada pasien usia lanjut bila tidak ditangani dengan baik. Pada pasien ini sudah mengalami imobilisasi selama 5 tahun terakhir dengan keadaan ketergantungan total saat masuk rumah sakit. ${ }^{13}$

Berdasarkan definisi, pasien geriatri memiliki karakteristik khusus yaitu terdapat lebih dari satu penyakit kronis degeneratif, hal ini merupakan karakteristik pertama yang disebut sebagai multipatologi. Karakteristik kedua yaitu terjadinya penurunan daya cadangan faali karena fungsi organ yang menurun akibat proses penuaan. Karakteristik ketiga adalah gejala dan tanda penyakit yang diderita pasien geriatri tidak khas. Karakteristik yang terakhir yaitu penurunan status fungsional yang merupakan kemampuan seseorang untuk melakukan aktivitas sehari-hari. Hal tersebut dapat menyebabkan pasien geriatri berada pada kondisi imobilisasi yang berakibat ketergantungan pada orang lain. ${ }^{14}$

Keadaan pasien saat masuk rumah sakit tergolong imobilisasi dengan ketergantungan total. Pada pasien ini juga mengalami instabilitas dengan resiko tinggi untuk jatuh. Salah satu tampilan klinis sindrom geriatri adalah instabilitas dan risiko jatuh yang pada geriatri merupakan permasalahan yang serius karena hal tersebut tidak hanya menyebabkan cedera melainkan juga dapat menyebabkan penurunan aktivitas, peningkatan utilisasi pelayanan kesehatan bahkan kematian. Intervensi untuk mencegah atau mengurangi risiko kejadian jatuh pada lansia membutuhkan kerjasama meliputi medis, rehabilitasi, serta pendekatan modifikasi lingkungan. Pedoman untuk evaluasi dan penatalaksanaan jatuh pada lansia dikeluarkan oleh American Geriatric Society, merekomendasikan untuk menanyakan kepada seluruh lansia mengenai riwayat jatuh dan kemungkinan terjadi ketidakstabilan. ${ }^{14}$

Pasien ini mengalami kondisi malnutrisi. Pasien mengalami kondisi malnutrisi dimana indeks masa tubuh kurang dari $18,5 \mathrm{~kg} / \mathrm{m}^{2}$. Penyebab malnutrisi pada pasien ini antara lain asupan yang tidak adekuat, kondisi gigi geligi yang buruk, adanya penyakit neurodegeneratif, kondisi imobilisasi dan ketergantungan total, serta pengetahuan mengenai gizi yang kurang pada anggota keluarga (caregiver). Malnutrisi merupakan karakteristik khusus pasien geriatri yang sering dijumpai di Indonesia. Dilaporkan bahwa malnutrisi merupakan sindrom geriatri terbanyak pada usia lanjut yang dirawat $(42,6 \%)$ di 14 rumah sakit. Nisa $\mathrm{H}$ telah melaporkan prevalensi status gizi kurang (IMT < 18,5) masih sangat tinggi pada panti Werdha di kawasan DKI Jakarta pada tahun 2004 yaitu sebesar 32,9 \%. Malnutrisi energi dan protein pada lansia berhubungan dengan gangguan fungsi muskuloskeletal, penurunan massa tulang, disfungsi imunitas, anemia, penurunan fungsi kognitif, penyembuhan luka yang buruk, dan pada akhirnya meningkatkan angka kesakitan dan kematian. Dengan demikian, intervensi yang bertujuan meningkatkan status gizi seseorang akan memberikan dampak pula 
pada peningkatan kualitas hidup, baik secara fisik maupun mental. ${ }^{15,16,17}$

Pasien ini mengalami hipoalbuminemia. Hipoalbuminemia telah lama diketahui sebagai salah satu penanda adanya risiko komplikasi perawatan di rumah sakit dengan perawatan yang lebih lama, meningkatnya jumlah kasus yang dirawat kembali, serta mortalitas lebih tinggi diantara pasien usia lanjut yang dirawat. Walaupun hipoalbuminemia telah umum diketahui sebagai penanda adanya malnutrisi energi protein, namun hipoalbuminemia juga berkaitan dengan adanya infeksi, inflamasi, stress pasca pembedahan, trauma, gangguan pencernaan, penyakit hati, ginjal, penyakit jantung. Hipoalbuminemia ditemukan $>70$ $\%$ pada populasi geriatri dan dikaitkan dengan menurunnya respon terhadap terapi sehingga masa penyenbuhannya akan lebih lama, memperpanjang masa rawat inap, menambah biaya rumah sakit, dan secara umum miningkatkan angka morbiditas dan mortalitas. Hipoalbuminemia sebagai salah satu faktor prognosis buruk terhadap perjalanan penyakit serta prediktor kematian pada populasi usia lanjut yang sakit. ${ }^{17}$

Pada pasien ini keadaan hipoalbuminemia dapat disebabkan karena infeksi yang dialami pasien. Pasien ini dengan CURB 65 dengan angka mortalitas sebesar 6,8 \% dalam 30 hari. Derajat beratnya pneumonia pada lansia juga berkaitan dengan hipoalbuminemia akibat proses infeksi akut yang dimediasi oleh sitokin-sitokin spesifik (seperti tumor necrosis factor dan interleukin- 6), meningkatkan hilangnya gradien konsentrasi normal antara ruang intra dan ekstravaskular. Sitokin-sitokin yang sama juga menekan sintesis albumin dan dapat memicu peningkatan degradasi albumin. Pada kondisi infeksi terjadi penurunan kadar albumin serum yang dimediasi oleh sitokinsitokin seperti IL-2, IFN-alpha, dan IL-6. Faktor-faktor yang berkontribusi dalam penurunan konsentrasi albumin serum masih menjadi kontroversi. Terdapat beberapa teori yang berusaha menjeaskan proses terjadinya hipoalbuminemia pada kondisi infeksi seperti adanya gangguan sintesis albumin saat inflamasi, sekuentrasi albumin ke ruang ekstravaskular, dan peningkatan katabolisme albumin. ${ }^{7}$

Selain akibat proses infeksi, keadaan hipoalbuminemia pada pasien ini dapat akibat malnutrisi. Albumin juga merupakan penanda kondisi malnutrisi. Pada keadaan malnutrisi energi - protein yang ringan, terjadi adaptasi tubuh untuk mempertahankan kadar albumin serum yang normal dengan jalan mengurangi proses katabolisme dan kembalinya albumin di jaringan interstisial ke ruang intravaskuler. Pada malnutrisi energi - protein yang sudah lanjut, proses adaptasi ini tidak dapat mengimbangi penurunan proses sintesis yang berhubungan dengan asupan nutrisi sehingga terjadilah hipoalbuminemia. ${ }^{7}$

Pasien mengalami gangguan elektrolit berupa hiponatremia. Hiponatremia didefinisikan sebagai kadar natrium plasma < $135 \mathrm{mmol} / \mathrm{L}$, merupakan gangguan keseimbangan cairan tubuh dan elektrolit yang paling sering ditemukan pada praktik klinis terutama pada geriatri. Manifestasi klinis hiponatremia dapat ditemukan dalam spektrum yang luas, mulai dari tidak bergejala sampai pada kondisi berat atau mengancam nyawa serta dikaitkan denga peningkatan mortalitas, morbiditas, dan lama perawatan di rumah sakit pada pasien dengan kondisi-kondisi tersebut. Beberapa kondisi yang dapat menyebabkan hiponatremia yaitu kekurangan hormon adrenal, diare atau muntah, syndrome of inappropriate anti diuretic hormone (SIADH), penggunaan obat-obat tertentu seperti diuretik, antidepresan, analgetik dan amfetamin. Adapun faktor risiko hiponatremia yaitu aktivitas fisik dan usia. Geriatri memiliki kecenderungan lebih 
tinggi mengalami hiponatremia. Kondisi hiponatremia pada geriatri berhubungan dengan prognosis yang buruk dan secara independen terkait dengan peningatan risiko kematian. Pada pasien ini keadaan hiponatremia di tatalaksana dengan pemberian $\mathrm{NaCl} 3 \%$ secara intravena. ${ }^{18,19}$

Pemberian nutrisi pada pasien harus memperhatikan risiko refeeding syndrome, yakni suatu kondisi berpindahnya cairan dan elektrolit yang terjadi pada saat pemberian asupan karbohidrat berlebihan setelah periode kelaparan yang cukup berat. Beberapa gambaran klinis yang terjadi antara lain gagal jantung kongestif, aritmia, anoreksia, mual, konstipasi, ileus, ataksia, paralisis, parestesia, anemia hemolitik, trombositopenia, bahkan koma. Refeeding syndrome dapat menyebabkan dampak buruk dan kematian. Refeeding syndrome merupakan suatu sindroma yang sering tidak terdiagnosis, oleh karena itu perlu peningkatan pengetahuan dan kesadaran dari tenaga medis untuk mengurangi morbiditas dan mortalitas dari sindroma ini. Sindrom ini dapat dicegah dengan mengenali faktor risiko pasien, pengawasan yang ketat, serta pemberian suplemen elektrolit. ${ }^{15}$

Pasien ini memiliki risiko tinggi untuk kejadian refeeding syndrome dengan IMT yang $<18,5 \mathrm{~kg} / \mathrm{m} 2$, asupan makan sedikit, dan penurunan $\mathrm{BB}>15 \%$. Sehingga nutrisi diberikan secara bertahap dan dititrasi naik hingga mencapai kebutuhan ideal. Selain itu diperlukan adanya pemantauan elektrolit. Rekomendasi dari Konsensus Asuhan Gizi pada Lansia dan Pasien Geriatri pada pasien dengan risiko tinggi mengalami refeeding syndrome, pemberian nutrisi dimulai dengan $10-15$ $\mathrm{kkal} / \mathrm{kgBB} / \mathrm{hari}$ (H1-3), dilanjutkan dengan 15 - $25 \mathrm{kkal} / \mathrm{kgBB} / \mathrm{hari}$ (H4-5), 30 $\mathrm{kkal} / \mathrm{kgBB} / \mathrm{hari}$ (H6) dan diberikan kebutuhan penuh pada hari ke $7 .^{20}$

Pasien ini juga menderita penyakit diabetes melitus, hipertensi dan stroke infark. Pasien geriatri sering diserta penyakit kronis degeneratif. Masalah yang muncul sering tumpang tindih dengan gejala yang sudah lama diderita sehingga tampilan gejala menjadi tidak jelas. Penyakit degeneratif yang banyak dijumpai pada pasien geriatri adalah hipertensi, diabetes mellitus, dislipidemia, osteoarthritis, penyakit kardiovaskular dan serebrovaskular. Penelitian multisenter di Indonesia terhadap 544 pasien geriatri yang rawat inap mendapatkan prevalensi hipertensi dan diabetes melitus sebesar 50,2 $\%$ dan $27,2 \%{ }^{9}$

Pengobatan pada pasien usia lanjut secara signifikan berbeda dari pasien pada usia muda, karena adanya perubahan kondisi tubuh yang disebabkan oleh usia, dan dampak yang timbul dari penggunaan obatobatan yan digunakan sebelumnya. Kondisi multipatologi mengakibatkan seseorang usia lanjut mendapatkan berbagai jenis obat dalam jumlah banyak. Masalah polifarmasi pada pasien geriatri sulit dihindari dikarenakan oleh berbagai hal yaitu penyakit yang diderita banyak dan biasanya kronis, obat diresepkan oleh beberapa dokter, kurang koordinasi dalam pengelolaan, gejala yang dirasakan pasien yang tidak jelas, pasien meminta resep, dan untuk menghilangkan efek samping obat justru ditambah obat baru. Karena itu prinsip pemberian obat yang benar pada pasien geriatri dengan cara mengetahui riwayat pengobatan lengkap, jangan memberi obat yang digunakan, mulai dengan dosis rendah, naikkan perlahan-lahan, obati sesuai patokan, beri dorongan supaya patuh berobat dan hati-hati menggunakan obat baru. Prinsip penggunaan obat yang benar dan tepat pada usia lanjut harus menjadi kajian multi/ interdisiplin yang mengedepankan pendekatan secara holistik. Pengelolan pasien secara bersama dalam tim medis interdisipliner dengan partisipasi keluarga 
merupakan salah satu pendekan pelayanan geriatri yang paripurna. ${ }^{9}$

\section{SIMPULAN}

Sindrom delirium akut melibatkan suatu hendaya fungsi kognitif yang akut dan menyeluruh yang mempengaruhi kesadaran, perhatian, memori dan kemampuan perencanaan dan organisasi. Sindrom delirium akut bersifat fluktuatif dan dapat reversibel jika penyebab yang mendasarinya teridentifikasi. Pengelolan pasien secara bersama dalam tim medis interdisipliner dengan partisipasi keluarga merupakan salah satu pendekatan pelayanan geriatri yang paripurna.

\section{DAFTAR PUSTAKA}

1. Andri, Damping CE. Peranan pskiatri geriatri dalam penanganan delirium pasien geriatri. Maj Kedokt Indon.2007;57(7):227-32.

2. Meagher DJ. Delirium. Optimizing management. Brint Med J.2001;322(20):144-8.

3. Rai D, Garg RK, Singh MK. Acute confusional state/delirium: An etiological and prognostic evaluation. Ann Indian Acad Neurol.2014;17(1):30-4.

4. Adiwinata R, Oktaliansah E, Maskoen TT. Angka kejadian delirium dan faktor risiko di Intensive Care Unit Rumah Sakit Dr.Hasan Sadikin Bandung. JAP.2016;491):36-41.

5. Welsh T, Gladman J, Gordon AL. Comprehensive geriatric assessmentA guide for the non-specialist.Int $\mathbf{J}$ Clin Pract.2014;68(3):290-3.

6. Shashidhar G, Sivaranjani K, Ammatalli NKR. A study of Comprehensive geriatric assessment in elderly patients in rural Bangalore.
International Journal of Contempory Medicine Surgery and Radiology.2018;3(3):C17-20.

7. Kurniawan W, Rumende CM, Harimurti K. Hipoalbuminemia pada usia lanjut dengan pneumonia komunitas : prevalensi dan pengaruhnya terhadap kesintaan. Jurnal Penyakit Dalam Indonesia. 2014;1(2):79-88.

8. Setiati S. Geriatric Medicine, Sarkopenia, frailty dan kualitas hidup pasien usialanjut : Tantangan Masa Depan Pendidikan, Penelitian, dan Pelayanan Kedokteran di Indonesia. e JKI. 2013;1(3):234-42.

9. Setiati S. Konsep kerapuhan (Frailty) pada usia lanjut : definisi, patobiologi, dan manajemen terkini. Perhimpunan Gerontologi Medik Indonesia. $2015: 1-18$.

10. Pelletier AL.Rojas-Roldan, Coffin J. Vision loss in older adults. Am Fam Physician.2016;94(3):p219-26.

11. Sharman A, Hindman HB. Review article aging : A predisposition to dry Eyes. Int J Ophthalmol.2014:1-9

12. Pereira MVC,Gloria ALF. Lagophthalmos. Semin Ophthalmol. 2010;25(3):72-8.

13. Laksmi PW, Harimurti K, Setiati S, Soejono CH, Aries W, Roosheroe AG. Management of immobilization and its complication for elderly. Indones J Intern ed. 2016: 232-40.

14. Safitri S. Instabilias dan kejadian jatuh pada lansia. J Agromed Unila. 2015;2(4): 504-9.

15. Setiati S, Laksmi PW. Pedoman asuhan nutrisi pada orang usia lansia 
dan pasien geriatri. Pusat Penerbitan Ilmu Penyakit Dalam. 2017.

16. Nisa H. Faktor determinan status gizi lansia penghuni panti werdha pemerintah DKI Jakarta Tahun 2004. Media Litbang Kesehatan XVI.2006;3:24-34.

17. Brock F, Bettinelli LA, Dobner T, Stobbe JC, Pomatti G, Telles CT. Prevalence of hypoalbuminemia and nutritional issues in hospitalized elders. Rev Lat Am Enfermagem. 2016;8(24):e2736.

18. Spasovski G, Vanholder R, Allolio B, Annane D, Ball S, Bichet D, et al. Clinical practice guideline on diagnosis and treatment of hyponatremia. Nephrol Dial Transplant.2014;29(2):ii1-39.

19. Filippatos TD, Makri A, Liamis G. Hyponatremia in the elderly : challenges and solutions. Clin Interv Aging. 2017;12:1957-65

20. David B. Principles of geriatric assessment. In : Halter, J.Hazzard's Geriatric Medicine and Gerontology. McGraw Hill Education.2017.p23650. 